Bull. Mater. Sci., Vol. 21, No. 6, December 1998, pp. 475-478. (C) Indian Academy of Sciences.

\title{
Fabrication of polycrystalline silicon solar cells showing high efficiency
}

\author{
MANAS KUMAR DAS* and N S CHICKERUR \\ Post-Graduate Department of Chemistry, Khallikote College (Autonomous), Berhampur 760 001, India \\ *Government Testing Laboratory, Industrial Estate, Berhampur 760008 , India \\ MS received 21 January 1998; revised 25 September 1998
}

\begin{abstract}
The paper presents a methodology for fabrication of low-costing silicon solar cells with an efficiency of $10 \%$. A polycrystalline silicon wafer, size $100 \times 100 \mathrm{~mm}$ and thickness $450 \mu \mathrm{m}$, was doped with phosphorus using $\mathrm{POCl}_{3}$ as the dopant. While, the backside ( $p$-side) of the wafer was printed with a paste of $\mathrm{Ag}+\mathrm{Al}$ in the ratio of $25: 1$, the front side ( $n$-side) was printed with a paste of silver. It was fired at $720^{\circ} \mathrm{C}$ for better ohmic contact. Chemical vapour deposition (CVD) method was adopted for antireflection coating. Pure oxygen gas was bubbled through a solution of $\mathrm{TiCl}_{4}$ at $200^{\circ} \mathrm{C}$. The fabricated cells gave a significant increase in efficiency in terms of open circuit voltage $(V) 560 \mathrm{mV}$, short circuit current $(I)$ of $2.7 \mathrm{amp}$, and fill factor of $\mathbf{0 . 7 3}$. The methods used are inexpensive, and suitable for production of efficient silicon solar on a commercial basis.
\end{abstract}

Keywords. Photogenerator carriers; anisotropic etching; oxidant; auger recombination.

\section{Introduction}

It is estimated by some experts that the fuel resources, including oil and natural gas, may last for less than half a century, while coal may last for hundred years. As an alternative and a sustainable source of energy, it is believed that the ultimate source to solve the energy crisis is solar energy. The most attractive source of this energy, at present, is a solar cell which is low costing as well as has high efficiency. Though quite a number of semiconductor materials are being used, amorphous, mono- and polycrystalline silicon are chosen for largescale utilization. Cocorullo et al (1984), and Pereyra and Andrade (1984) tried to reduce cost of fabrication of the silicon solar cell by nickel deposition technique that resulted in the formation of nickel-silicon alloy at the silicon interface. Banerjee et al (1987) adopted optical concentrators to reduce the cost of the photovoltaic system, known as concentrator photovoltaic system (CPVS). For better results, hydrogen passivation technique was used by Wallace et al (1994). Development of low costing polycrystalline silicon solar cells has recently been achieved by improvement of substrate quality, enhancement of passivation effect etc by Nakaya et al (1994). Pugacz-Muraszkiewicz and Hammond (1977) reported that the matte surface structure, that contains pyramids of height of about $10 \mu \mathrm{m}$, reduces reflectivity of the incident light falling on the cell surface and thus enhances the probability of light absorption, thereby

\footnotetext{
*Author for correspondence
}

leading to increase of photo generator carriers; i.e. enhances the efficiency of the cells. Campbell and Green (1987) developed such textured surface by anisotropic etching, using an acid mixture $\mathrm{HF}: \mathrm{HNO}_{3}$ : $\mathrm{CH}_{3} \mathrm{COOH}::: 1: 3: 1$. Further, it is also known that the efficiency of the cell depends upon the thickness of the slices as well as the impurity, here phosphorus, in the semiconductor. The authors report simple methodology adopted by them for production of low-cost silicon solar cells with an efficiency of $10 \%$. Different aspects involved in their fabrication are discussed below.

\section{Methodology}

\subsection{Fabrication of $P-N$ junction}

A sample of multicrystalline silicon sheet of size $100 \times 100 \mathrm{~mm}$, and thickness of about $450 \mu \mathrm{m}$, and with resistivity ranging from 0.5 to $5.0 \Omega \mathrm{cm}$ of type $-\mathrm{P}$ with boron dopant was used. The surface was polished in $30 \% \mathrm{NaOH}$ followed by treatment with an acid mixture, $\mathrm{HF}: \mathrm{HNO}_{3}: \mathrm{CH}_{3} \mathrm{COOH}::: 1: 3: 1$ for $2 \mathrm{~min}$.

\subsection{Surface texturization}

The surface was cleaned several times in deionized water and texturized using a solution of $1-2 \% \mathrm{KOH}$ at $60^{\circ} \mathrm{C}$. (While the acid etching produces pyramid structures that absorb about $56 \%$ of light striking the surface, and thereby increases the photo-generation capacity, potassium 
hydroxide acts as an oxidant and removes the dead layer of Si-P on the surface so that the photovoltaic effects are enhanced). The treated silicon sheet was kept in a hot air oven for about $2-3 \mathrm{~h}$ and was placed in a closed quartz tube through which a mixture of $\mathrm{N}_{2}$ and $\mathrm{O}_{2}$ (10:1) was passed. Diffusion was carried out at $900^{\circ} \mathrm{C}$, using $\mathrm{POCl}_{3}$ liquid diffusion for $1 \mathrm{~h}$ at $18^{\circ} \mathrm{C}\left( \pm 1^{\circ} \mathrm{C}\right)$. The slices were arranged parallel to the direction of flow of the gas. To avoid decomposition of $\mathrm{POCl}_{3}$, a system $\left(\mathrm{PCl}_{5}+\mathrm{H}_{2} \mathrm{O}\right)$ cooled under ice was used as diffusion source. $\mathrm{POCl}_{3}$ thus generated is stable in presence of nitrogen under normal conditions. Wallace et al (1994) and Agarwal et al (1997) showed that microscopic structural defects, resulting in surface recombination and auger recombinations during phosphorus diffusion process on silicon surface, were reduced at the chosen temperature of $900^{\circ} \mathrm{C}$. After diffusion, while a photoresistant (PR) coating was given on the frontside, the backside of the slice was etched with an acid mixture, mentioned earlier, for $15 \mathrm{sec}$. Trichloroethylene and isoproponal were used for the final cleaning of the surface.

\subsection{Printing and metallization}

The frontside of the cell was coated with silver paste to which about 6-10 drops of terpentine oil and rosin mixture was added as thinner. Different patterns were printed by selecting stainless steel mesh (\#150) (figure 1). The cell was then dried for few min first in air and later under infrared lamp. In case of pattern design shown in figure $1 d$, it was observed that there was only $8 \%$ shading loss and hence higher efficiency.

The backside of the cell was coated with a paste of $\mathrm{Ag}+\mathrm{Al}$ in the ratio of $25: 1$. It was sintered at about

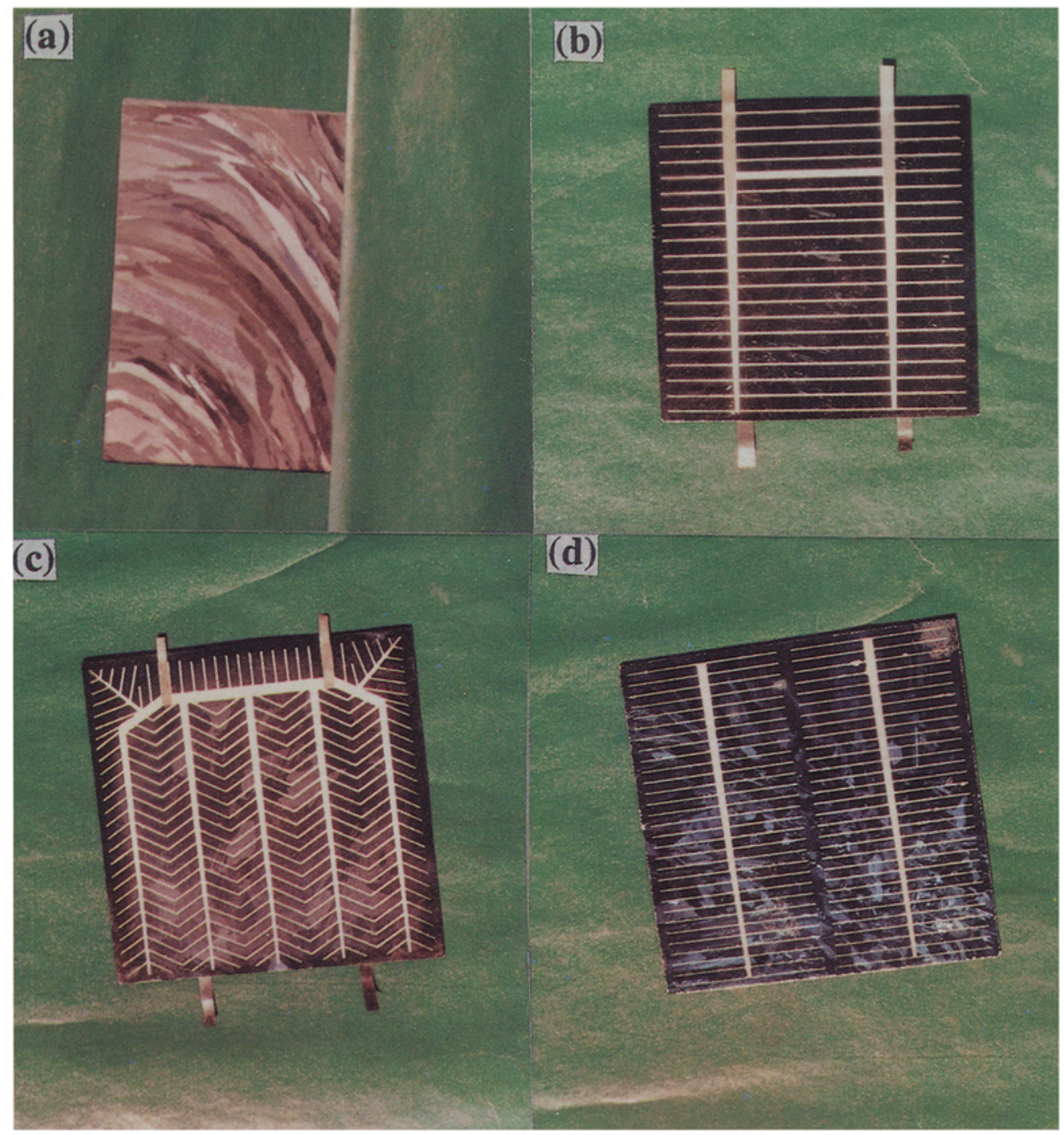

Figure 1. Different patterns printed on silicon slices. (a) Diffused silicon wafer and (b)-(d) show pattern designs. 
$720^{\circ} \mathrm{C}$ in an open tube furnace using compressed air. Optimization of sintering temperature is given in table 1. The mixture of $\mathrm{Ag}+\mathrm{Al}$ used as a paste for coating increased ohmic contact between the semiconductor and the metal.

\subsection{Thickness of slices and efficiency}

The transparency of the slices was studied up to the thickness of $370 \mu \mathrm{m}$ (table 2). It was observed that the thickness of the slices as well as the impurity concentration in the semiconductor-in this case phosphorus atom-affect the extent of energy conversion. Since it is difficult to control impurity concentration in the semiconductor during phosphorus diffusion, the control is therefore managed by altering the thickness of the silicon slices. The thickness of about $450 \mu \mathrm{m}$ recorded the maximum value of open circuit voltage $(V)$ and short circuit current (I) (table 3).

\subsection{Antireflection coating (ARC)}

For antireflection coating, first chemical vapour deposition (CVD) with titanium isopropoxide using $\mathrm{N}_{2}$ gas was tried. Since it was not successful, $\mathrm{TiCl}_{4}$ and $\mathrm{O}_{2}$ were used at the cell temperature of $200^{\circ} \mathrm{C}$. The results given

Table 1. Optimization of sintering temperature of the printed cell. After firing and antireflection coating the cells were measured at supply voltage of 235 volt.

\begin{tabular}{lccc}
\hline $\begin{array}{c}\text { Sintering } \\
\text { no. }\end{array}$ & $\begin{array}{c}\text { temperature } \\
\left({ }^{\circ} \mathrm{C}\right)\end{array}$ & $\begin{array}{c}V \\
(\mathrm{mV})\end{array}$ & $\begin{array}{c}I \\
\text { (amp) }\end{array}$ \\
\hline 1 & 650 & 515 & 1.30 \\
2 & 700 & 525 & 1.71 \\
3 & 710 & 530 & 1.96 \\
4 & 720 & 543 & 2.52 \\
5 & 730 & 520 & 1.67 \\
6 & 750 & 523 & 0.70 \\
\hline
\end{tabular}

Table 2. Dependence of light transparency of silicon slice on thickness. Measurement of open circuit voltage (V) at supply voltage of 235 volt. A cell giving $V=506 \mathrm{mV}$ originally was covered with silicon of different thickness shown in the table. The original value decreases from $506 \mathrm{mV}$ to $182 \mathrm{mV}$.

\begin{tabular}{lcc}
\hline $\begin{array}{l}\text { Sl. } \\
\text { no. }\end{array}$ & $\begin{array}{c}\text { Thickness } \\
\text { of the } \\
\text { slices }(\mu \mathrm{m})\end{array}$ & $\begin{array}{c}\text { After } \\
\text { covering } V \\
(\mathrm{mV})\end{array}$ \\
\hline 1 & 370 & 182 \\
2 & 350 & 187 \\
3 & 300 & 218 \\
4 & 245 & 242 \\
5 & 220 & 254 \\
\hline
\end{tabular}

in table 4 show that the reflectivity of the surface was reduced and more photovoltage generated. For domestic application $\frac{1}{2}, \frac{1}{4}$ cells and $1 / 16$ cells were prepared from the original cell, and the quarter cells showed reasonable efficiency (table 5). A flow chart of fabrication process of polycrystalline silicon solar cell is given in figure 2 .

\section{$2.6 V-I$ characteristics}

The $V-I$ characteristics of fabricated solar cells were studied, and are graphically represented in figure 3 . The

Table 3. Optimization of thickness of the slices. The open circuit voltage $(V)$ and short circuit current $(I)$ were recovered at supply voltage of 235 volt.

\begin{tabular}{lccc}
\hline Sl. & $\begin{array}{c}\text { Thickness of } \\
\text { the slices } \\
(\mu \mathrm{m})\end{array}$ & $\begin{array}{c}V \\
(\mathrm{mV})\end{array}$ & $\begin{array}{c}I \\
(\mathrm{amp})\end{array}$ \\
\hline 1 & 450 & 539 & $2 \cdot 72$ \\
2 & 350 & 527 & $2 \cdot 27$ \\
3 & 250 & 520 & $2 \cdot 10$ \\
\hline
\end{tabular}

Table 4. Effect of antireflection coating on open circuit voltage $(V)$ and short circuil current ( $/$ ) at supply voltage of 235 voll

\begin{tabular}{lcccc}
\hline $\begin{array}{l}\text { Sl. } \\
\text { no. }\end{array}$ & $\begin{array}{c}V \\
(\mathrm{mV})\end{array}$ & $\begin{array}{c}I \\
(\mathrm{amp})\end{array}$ & $\begin{array}{c}V \\
(\mathrm{mV})\end{array}$ & $\begin{array}{c}I \\
(\mathrm{amp})\end{array}$ \\
\hline 1 & 535 & 2.08 & 530 & 2.60 \\
2 & 552 & 1.88 & 545 & 2.59 \\
3 & 552 & 1.90 & 550 & 2.60 \\
4 & 552 & 2.04 & 550 & 2.67 \\
\hline
\end{tabular}

Table 5. Efficiency of cells of different sizes measured in terms of open circuit voltage $(V)$ and short current $(I)$ at supply voltage of 235 volt.

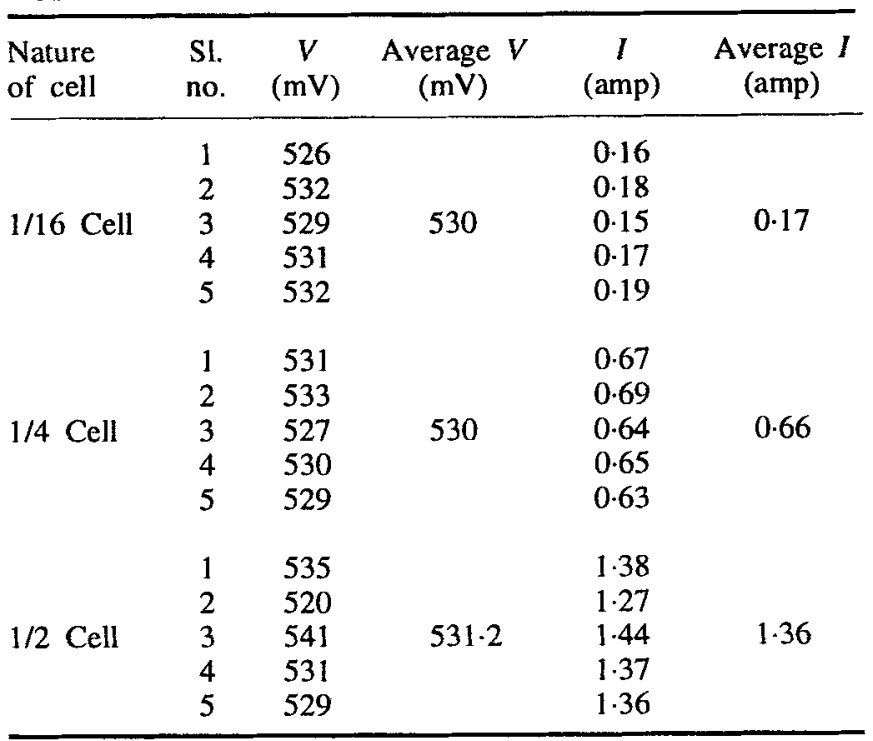




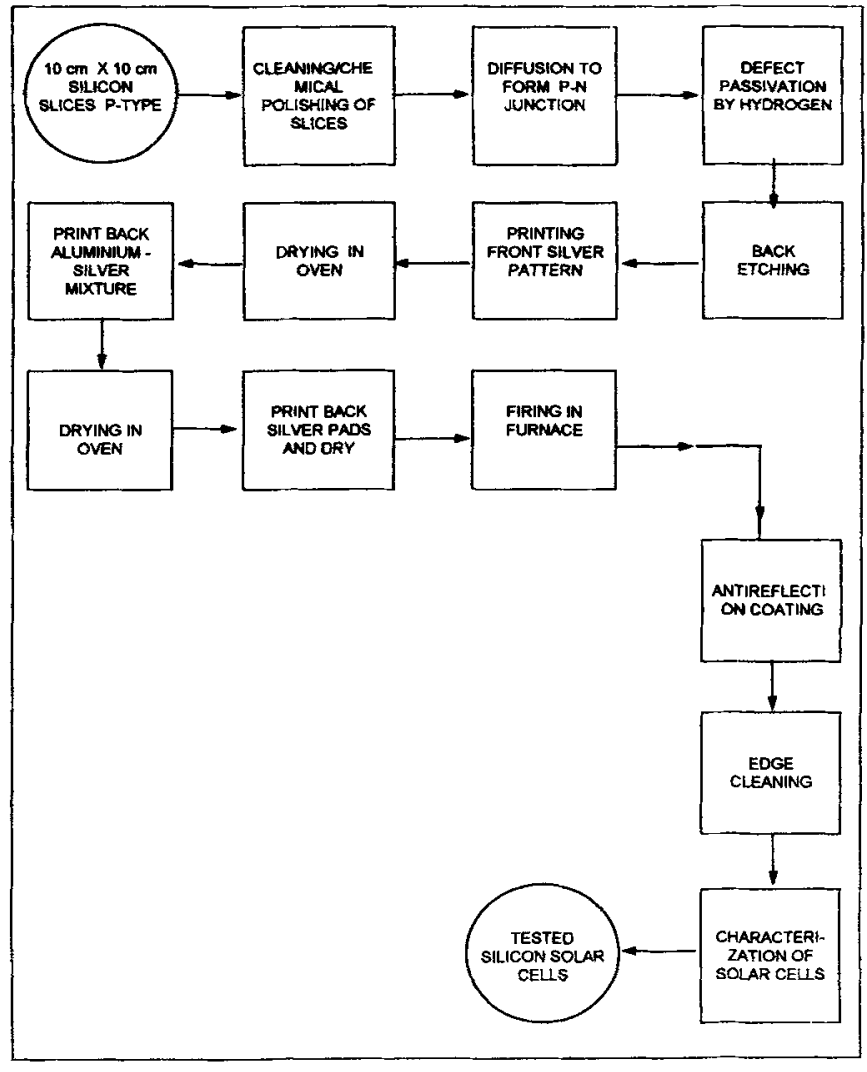

Figure 2. A flow sheet diagram for the assembly of solar cell.

figure shows efficient ohmic behaviour of the cell under one sun, and half sun conditions. While six halogen lamps were used to simulate the natural sunlight under one sun, for half sun three halogen lamps were used.

\section{Conclusion}

For the production of commercial low-cost solar cells, the silicon slices of $450 \mu \mathrm{m}$ thickness on which the P-N junction was made were selected. $\mathrm{POCl}_{3}$ solution, maintained at about $18^{\circ} \mathrm{C}$, was used as a dopant. Acid mixture $\mathrm{HF}: \mathrm{HNO}_{3}: \mathrm{CH}_{3} \mathrm{COOH}::: 1: 3: 1$ was used for backside etching and a paste of $\mathrm{Ag}+\mathrm{Al}$ in the ratio of $25: 1$ to increase ohmic contact was used for backside coating of the cell. Close grid pattern on the frontside of the cell and use of $\mathrm{TiCl}_{4}$ as antireflection coating, increased efficiency of the cell.

\section{Acknowledgements}

The author (MKD) wishes to express his gratefulness to the Director, Export Promotion and Marketing, Govt.
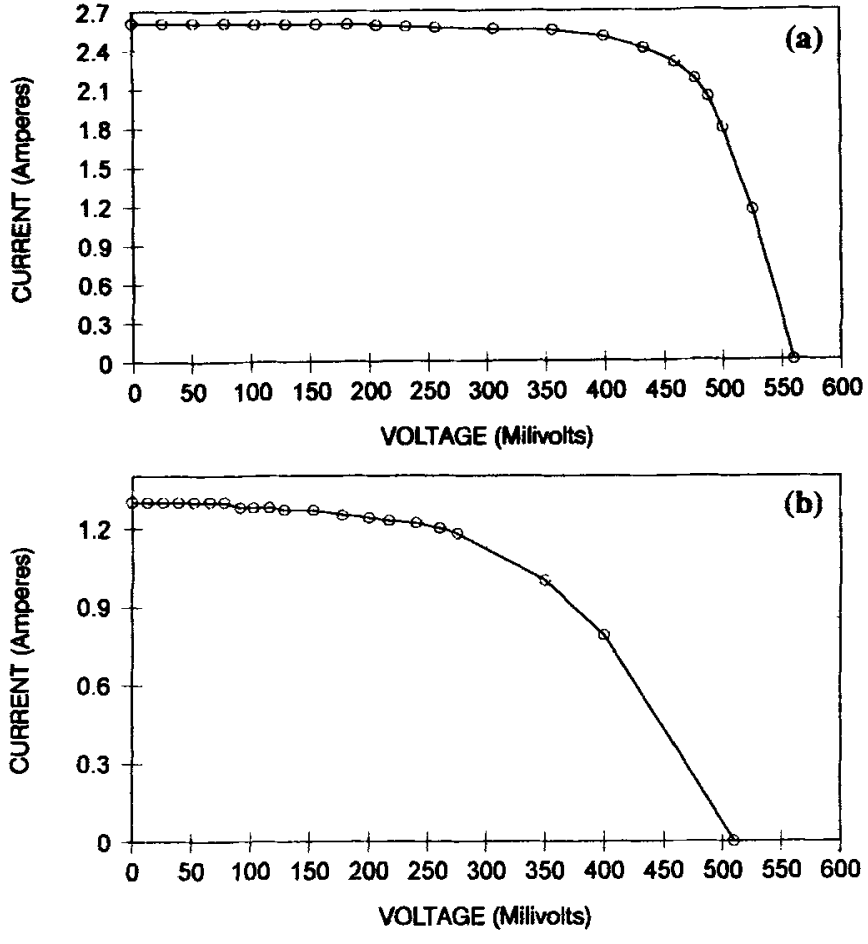

Figure 3. $V-I$ characteristics of the silicon solar cell under (a) one sun and (b) half sun.

of Orissa and Principal, Khallikote College, Berhampur, for facilities. Special thanks are also due to R\&D wing of IMFA, Therubali, for providing the necessary facilities to carry out a part of the work.

\section{References}

Agarwal S C 1997 Bull. Mater. Sci. 20379

Banerjee A, Bhattacharya G, Gangopadhyay U, Basu P and Saha H 1987 J. Solar Energy Soc. India 175

Campbell P and Green M A 1987 J. Appl. Phys. 62 243

Cocorullo G, Prezioso G and Zarcone M 1984 Solar Cells 11 19

Nakaya H, Nishida M, Takeda $Y$, Moriuchi S, Tonegawa T, Machida T and Nunoi T 1994 Solar Energy Mater. \& Solar Cells 34219

Pereyra I and Andrade A M 1984 Solar Cells 12285

Pugacz-Muraszkiewicz I J and Hammond B R 1977 J. Vac. Sci. Technol. 1449

Wallace R, Yi J, Palmer R and Anderson W A 1994 Solar Energy Mater. \& Solar Cells 39145 